九州大学学術情報リポジトリ

Kyushu University Institutional Repository

\title{
Deterministic Optimization of Irrigation Water Allocation in a Low-lying Paddy Area with Creek Networks
}

Jayadi, Rachmad

Laboratory of Irrigation and Water Utilization Engineering, Faculty of Agriculture, Kyushu University

Fukuda, Tetsuro

Laboratory of Irrigation and Water Utilization Engineering, Faculty of Agriculture, Kyushu University

Nakano, Yoshisuke

Laboratory of Irrigation and Water Utilization Engineering, Faculty of Agriculture, Kyushu University

Kuroda, Masaharu

Laboratory of Irrigation and Water Utilization Engineering, Faculty of Agriculture, Kyushu University

https://doi.org/10.5109/24343

出版情報：九州大学大学院農学研究院紀要. 44 (3/4)，pp.419-429，2000-02. Kyushu University バージョン：

権利関係: 


\title{
Deterministic Optimization of Irrigation Water Allocation in a Low-lying Paddy Area with Creek Networks
}

\author{
Rachmad Jayadi, Tetsuro Fukuda, Yoshisuke Nakano and Masaharu Kuroda
}

Laboratory of Irrigation and Water Utilization Enginecring, Faculty of Agriculture, Kyıshu University, Hakozaki, Higashi-ku, Fukuoka 812-8581, JAPAN

(Received October 29, 1999 and accepted Novernber 5, 1999)

\begin{abstract}
In a low-lying paddy area with creek networks, cyclic use of irrigation return flow can be easily performed. Therefore, water supply in this system can be less than the sum of water requirement of all paddy fields in the area. The deterministic dyndmic: programming model was used for optimizing the water supply for the systern. The model was first formulated with the objective function of minimizing water demand from creck-fields system on the main canal system. Time series of the existing and the optimized water supply to crecks, water application for paddy fields and the change of creck water depth were analyzed as a basis for clarifying the possibility of improving operation of water allocation in the irrigated area. It was shown that the optimum operation yielded better results than the actual condition, in which the effective use of water could be increased significantly. This paper also investigated the characteristics of content ratio of total return flow in creeks (CTRO) as one of indicalors for examining the impact of minimizing irrigation water supply to the change of water quality. The results suggested that the further research is needed to take into account CTRO to maintain the quality of irrigation water that is suitable for paddy rice cultivation.
\end{abstract}

Key words: Reiurn flow irrigation syster, Dynantic programming model Effectioe use of water, Retum flow content ratio, Water quality

\section{BACKGROUND OF STUDY}

Clarification of water demand and supply is required to establish the appropriate control method of operation of an irrigation system. In a large-scale paddy fields irrigation system, water that has been consumed by percolation, seepage and water that has been drained into canals can in some cases be reused inside the irrigated area. Thus the water requirement for the whole irrigation system is not simply the sum of water requirement of all paddy fields in the area. This phenomenon is commonly exists in a low-lying paddy area with creek networks.

One of the well known artificially reclamation areas in Japan is a low-lying paddy area of the Kase river irrigation system located in Saga plain facing the Ariake bay as shown in Fig. 1. The system is characterized by the existence of cyclic use of return flow for agricultural purposes, particularly for paddy rice cultivation. Irrigation water supply for the Kase river irrigation system is taken from the headwork of diversion through the main canal system in which the water flows to the delivery gates to each block of creek networks. According to the results of previous study (Kuroda and Cho, 1988), it was found the possibility of improving the performance of an operation of the irrigation system. The authors compared the actual and the simulated effective use of irrigated water obtained by the deterministic dynamic programming model. In this case, the ratio 
of the effective use of water in paddy fields by pumping system to the supplied water at the diversion headwork was employed for measuring the yield of operation of water supply. Even though the reused water irrigation system clearly yields the high efficiency of water use, but its severe impact on water quality has been shown in the previous study (Jayadi et al, 1998).

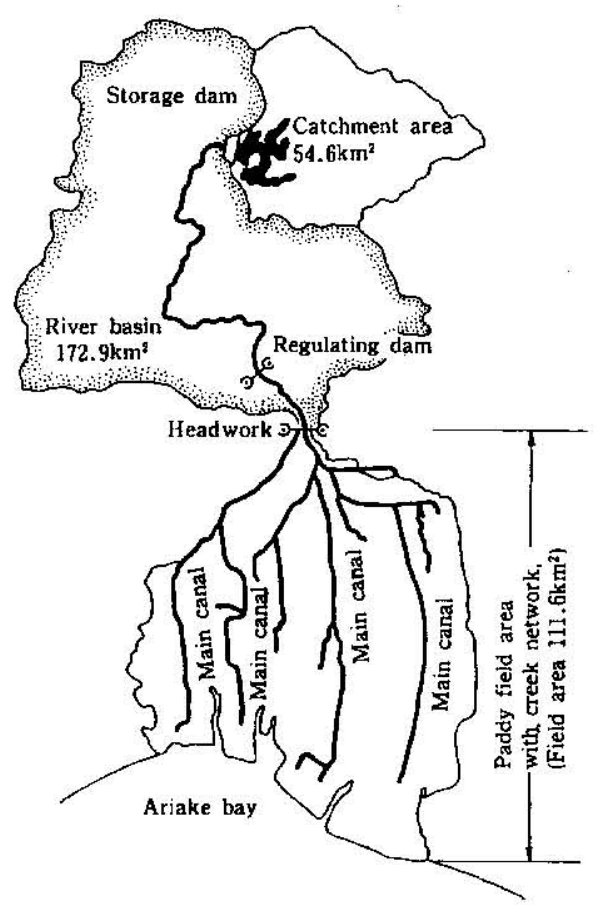

Fig. 1. Kase river irrigation system

Based on the above results, a further detail study is needed to verify whether the optimization results of the water use workable in a real operational for each block of paddy field areas. The aim of the study is to look for the possibility of water allocation optimization by minimizing irrigation water supply from the main canal to each creek networks. Due to the existence of relationship between the amount of water supply from the main canal to creek networks and the content ratio of total return flow in creek storage, optimization results will be evaluated by taking into account return flow as one of indicators of water quality condition at creeks. This evaluation is required for determining an ideal operation rule of water allocation at the study area.

\section{PROCEDURES FOR ANALYSES}

\section{Characteristics of the Irrigated Area}

A low-lying paddy area situated at the Oide district, Saga plain was chosen as a case 
study. The system is being a part of the Kase river irrigation system that consists of five blocks of area with creek networks namely block C, D, E, F, and G. The surveyed area is characterized by the existence of return flow irrigation system in which the water circulation between creeks and the cultivated areas occurs intensively as shown in Fig. 2, particularly due to return flow from paddy fields. Therefore, unlike the conventional irrigation system, the water demand for paddy fields is not directly related to the water supply from the main canals. In this system, creeks possess the buffer function in water demand that largely depends on the control of water level in creeks.

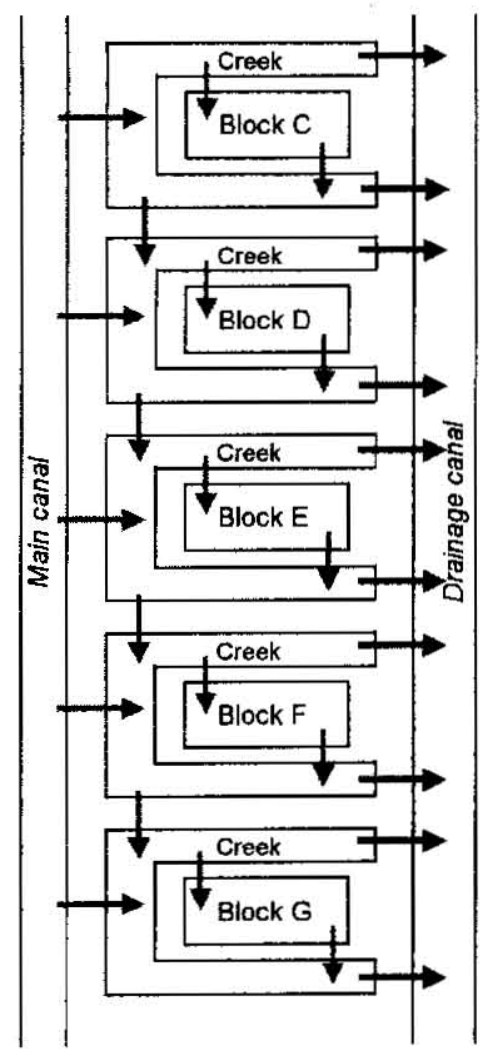

Fig. 2. Schematic representation of the water circulation in creek-fields system

\section{Water Balance in the Creek-Fields System}

A suitable illustration of the general water balance for each block of creek-fields system is shown in Fig. 3. The irrigation water is first supplied from the main canal to creeks through intakes operated by the local irrigation association using delivery gates. 


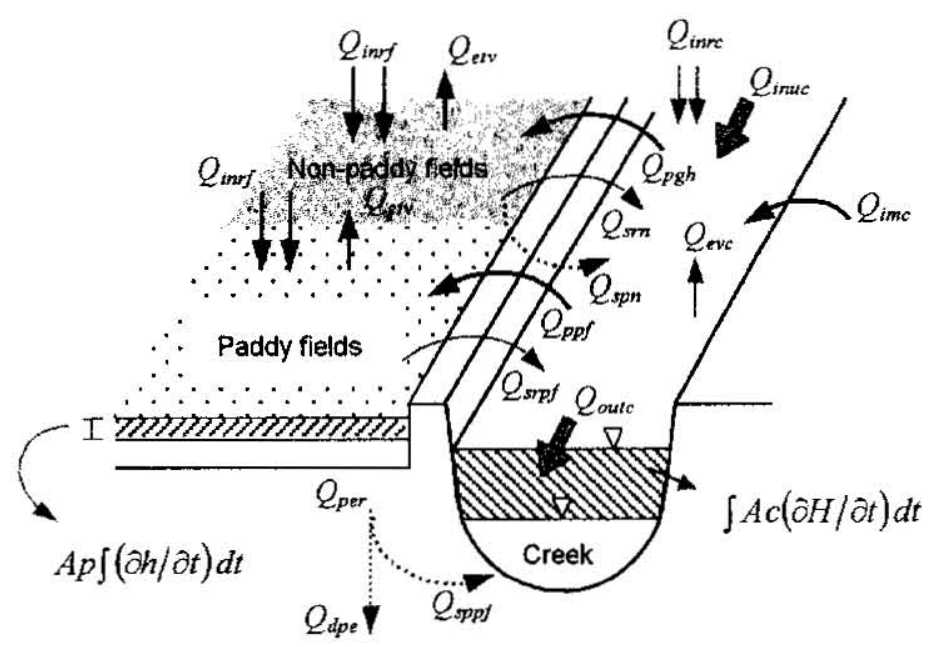

Fig. 3. General water balance in a block of creek-fields system

Since the water level in creeks is always lower than the level of the cultivated area, pumping system is used for irrigating paddy fields $\left(Q_{\eta m}\right)$ and non-paddy fields $\left(Q_{p \times t h}\right)$. The equation of water balance for paddy fields is given as follows.

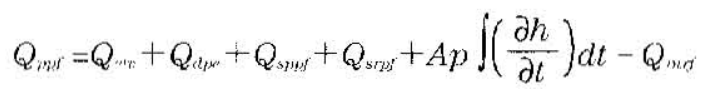

Water balance in creeks:

$$
\begin{aligned}
& Q_{\text {imm }}=Q_{\text {rep }}+Q_{\text {pai }}+Q_{\text {werc }}+Q_{\text {out }}+\int A c\left(\frac{\partial H}{\partial t}\right) d t-Q_{\text {in }}
\end{aligned}
$$

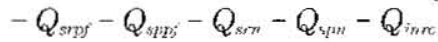

in which $Q_{p p s}$ is water supply from creeks to paddy fields by pumping, $Q_{e \text { ?: }}$ is

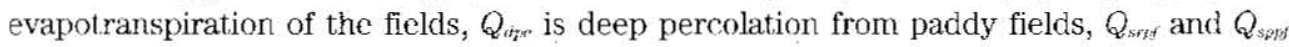
are surface and seepage runoff return flow from paddy fields respectively, $Q_{p \times r}$ is percolation from paddy fields in which its total amount is equivalent to $Q_{d p e}+Q_{\text {sipps }}$, $A_{\Gamma}(\partial h / \partial t) d t$ is change in storage of paddy fields, $Q_{n t r}$ is effective rainfall to the fields, $Q_{m}$ is water supply from the main canal to creeks, $Q_{r y j k}$ is water supply to greenhouses from creeks by pumping, $Q_{\text {eic }}$ is evaporation from creeks, $Q_{\text {ouc }}$ is runoff from creeks to out of the system, $\int A c(\partial H / \partial t) d t$ is change of water storage in creeks, $Q_{i m \text { m }}$ is runoff from the upper block of creek networks, $Q_{s m}$ and $Q_{\text {s\%m }}$ are surface and secpage runoff return flow from non-paddy fields respectively, and $Q_{\text {mirc }}$ is rainfall to creeks.

\section{Simulation of Optimum Water Supply from the Main Canal to Creeks}

There is no discharge measurement device installed at intake gates of the main canal. Therefore, it is difficult to evaluate accurately the existing amount of water supplied from the main canal to creeks. Jayadi et al (1998) applied complex Tank model to clarify the 
rcusc mcchanism of irrigation return flow and to estimate the amount of irrigation water delivered from the main canal to cach block of creek networks. The result showed that the complex Tank model proved the possibility of simulating the daily water allocation at the whole system within the existing operation. For this reason, it is necessary to extend the observation by optimizing the time series of water supply from the main canal to creeks.

In order to improve the efficiency of water use, the accurate quantitative information on the optimum water demand is great of importance. In this investigation the deterministic dynamic programming (DDP) model was used for obtaining the optimum values of daily water allocation in each block of the cultivated area. Having the optimized values of Tank model parameters, the $D D P$ model was simply formulated as follows.

The objective function $(O F)$ is to minimize the total amount of water supply from the main canal to creeks during irrigation season.

$$
O F^{\top}=\min \sum_{i=1}^{n} Q_{i m}^{i}
$$

Water supply to creeks $\left(Q_{i m}^{i}\right)$ has been defined in Eq. (2) for the $i^{t h}$ day of the irrigation period ( $n$ days). The depth of water in creeks $(H)$ and water pond at paddy fields $\left(h^{i}\right)$ were treated as the state variables in which the decision variables of water supply from the main canal to creeks $\left(Q_{i m}^{i}\right)$ and water supply to paddy fields from creek by pumping $\left(Q_{i n n}^{i}\right)$ have to be calculated through the algorithm of the $D D P$ model. The limiting conditions were capacity of pumps, minimum and maximum water depths at creeks, minimum and maximum depths of flooding water at paddy fields. The minimum flooding depth at paddy fields was given as the normal ponding depth. Table 1 shows the parameters and limiting conditions for applying the $D D P$ model.

Table 1. Parameters and limiting conditions for applying the $D D P$ model

\begin{tabular}{|c|c|c|c|c|c|c|c|c|}
\hline \multirow{2}{*}{ Block } & \multirow{2}{*}{$\begin{array}{l}\text { Paddy ficlds } \\
\text { (ha) }\end{array}$} & \multirow{2}{*}{$\begin{array}{l}\text { Creeks } \\
\text { (hia) }\end{array}$} & \multicolumn{2}{|c|}{$H(\mathrm{~cm})$} & \multicolumn{2}{|c|}{$h(\mathrm{~mm})$} & \multirow{2}{*}{$\begin{array}{c}\operatorname{Min} Q_{m} \\
(\mathrm{~mm} / \text { day })\end{array}$} & \multirow{2}{*}{$\begin{array}{l}\operatorname{Max} Q_{m y s} \\
(\mathrm{~mm} / \mathrm{day})\end{array}$} \\
\hline & & & $\min$ & $\max$ & min & $\max$ & & \\
\hline C & 301 & 16.6 & 130 & 210 & 45 & 60 & 2.5 & 50.0 \\
\hline $\mathrm{D}$ & 357 & 38.4 & 100 & 175 & 45 & 60 & 2.5 & 50.0 \\
\hline $\mathrm{E}$ & 174 & 19.5 & 75 & 175 & 45 & 60 & 2.5 & 50.0 \\
\hline$F$ & 263 & 24.0 & 80 & 180 & 45 & 60 & 2.5 & 50.0 \\
\hline $\mathrm{G}$ & 277 & 25.6 & 100 & 185 & 45 & 60 & 2.5 & 50.0 \\
\hline
\end{tabular}

Notes: 1) The unit of mm/day was derived with respect to the area of paddy fields at each block.

2) Feasible values of $H$ and $h$ were selected by the increment of $1 \mathrm{~cm}$ and $1 \mathrm{~mm}$, respectively.

According to the standard algorithm of the DDP method (Mays and Tung, 1992), the solution began with the backward recursive calculation by finding the optimal decision for each possible state in the last stage. The next step was forward run of simulation on the optimum values of daily water supply to creeks based on the constraints involved in the 
formulation of the model. The recursive equation of the backward calculation for stage $i$ can be expressed as follows.

$$
F^{\prime}\left(H^{\prime}, h^{i}\right)=\min _{Q_{i m, Q_{i, s}^{i}}}\left\{Q_{i m e}^{i}+F^{i-1}\left(H^{i-1}, h^{i-1}\right)\right\}
$$

in which $F^{i}\left(H^{i}, h^{i}\right)$ is the minimum value of water supply from the main canal to creeks by the optimum operation of the system over last $i$ days associated with $H^{i}$ and $h^{i}$. For the beginning backward calculation, i.e. at stage 1 , the recursive equation become:

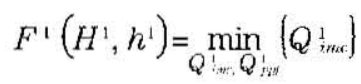

To solve Eq. (4) and (5), the state transformation function of Eq. (2) was applicable for evaluating the feasibility of the selected value of $Q_{i m s}^{i}$. In line to the objective function of the optimization, $Q_{m, n}^{\prime}$ was given as a certain amount of water supply to paddy fields from creeks required for keeping the ponding depth that not less than the normal depth $\left(h_{m+a}\right)$.

\section{RESULTS AND DISCUSSION}

The formulated optimization of $D D P$ model was sequentially applied from the upper block to the lower block of the irrigated areas. Based on the existing operation of 1998 , the hydrological data and the observed data of creek water depths were used for simulating the daily water supply from the main canal to creeks. These data were then used for running the model and making analysis on the possibility of minimizing the water demand from creek-fields system.

\section{Optimum Time Series of Water Supply and Creek Water Depth}

Fig. 4 depicts examples of the results for block C, E, and G. The observed and the optimum time series of water depth in creeks and those of the water supply from the main canal to creeks are drawn for the paddy season of 1998 . The results show that the optimum water depth in creeks is slightly lower than the observed one. The difference between the optimum and the observed water depths tends to decrease for the lower or downstream block. The observed water depth is highly responsive to high rainfall; otherwise the fluctuation of optimom water depth is relatively small.

At the end of paddy season, the observed water depth tends to increase especially at block C. In this period, however, an actual water demand for paddy fields is relatively small. The increasing water depth occurs due to substantive amount of rainfall that could not be anticipated in advance by gate operators. Beside that, in order to maintain the suitable water quality, the gate operators want to keep the water dcpth in creeks at a certain level by continuing water supply to creeks. This occurrence is due to the fact that continuing water supply from the main canal will reduce the concentration of water pollutant in creeks as a result of reused water mechanism.

On the other hand, the optimum water supply from the main canal to creeks is more responsive to rainfall. It implies that in the high rainfall, it is enough to supply water at the minimum requirement. At the top block $\mathrm{C}$, the simulation and that observed of water supply are relatively higher than those at the lower blocks. This phenomenon occurs 

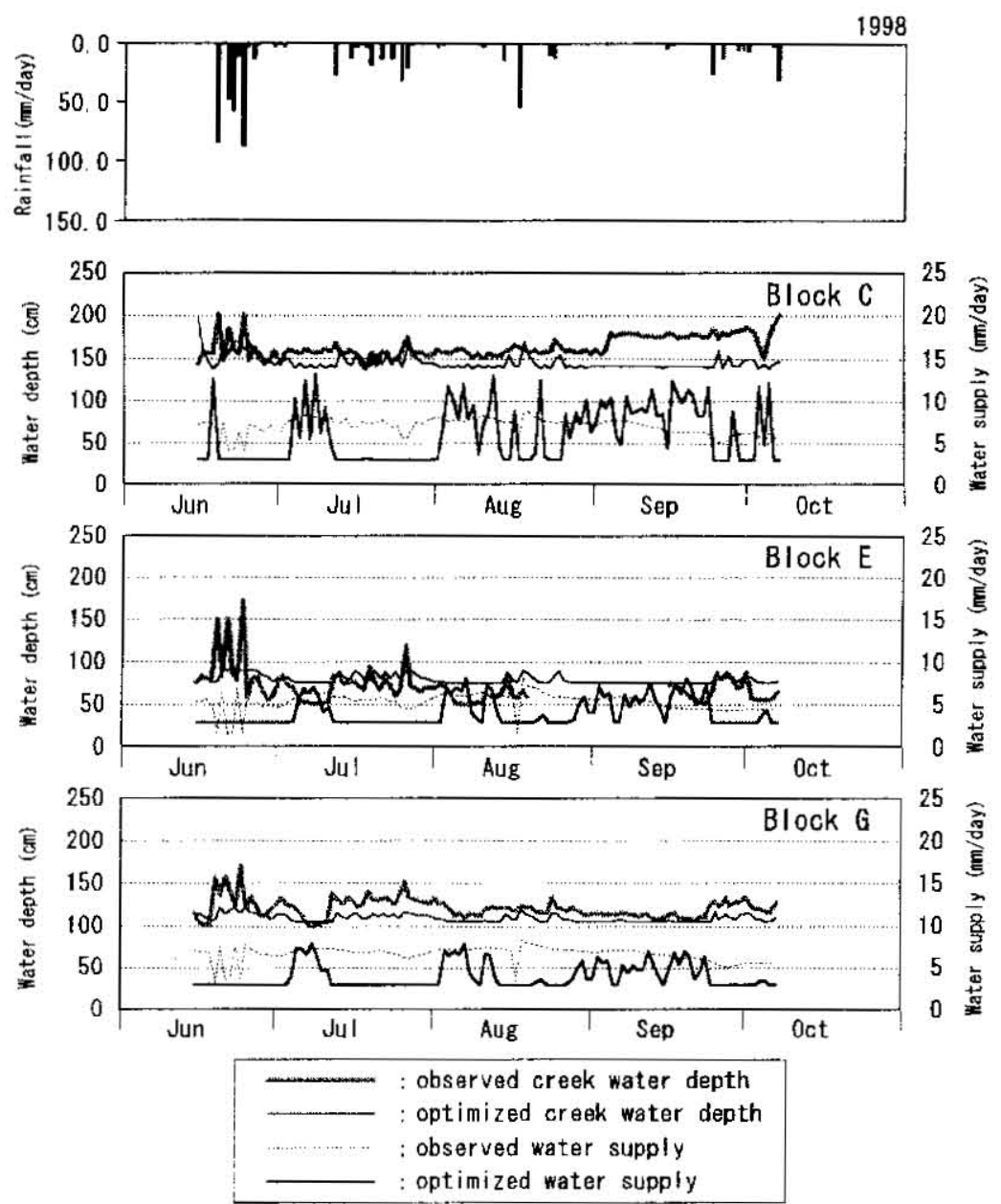

Fig. 4. Time series of creek water dopth and water supply from the main canal in block $\mathrm{C}, \mathrm{E}$ and $\mathrm{G}$ for the paddy season of 1998

since water supply for the top block $\mathrm{C}$ comes from the main canal only, whereas at the lower blocks comes from the main canal and return flow from the upper block. In this case, supplied water to block $\mathrm{C}$ includes for the lower block. Therefore, the optimum water supply allocated to creeks at the lower blocks is more efficient. It is indicated by the significant difference between the optimum and the observed water supply.

Those phenomena can be explained as follows. Since return flow at the upper block will be accumulated in sequence at the lower blocks, as a result water supply from the main canal tends to decrease at the lower blocks. 


\section{Optimum Water Application to Paddy Fields}

In order to elucidate the performance of water use in paddy fields, the optimum water supply from creeks to paddy fields was compared to the existing value obtained by the simulated operation of water supply by pumping. Fig. $\mathbf{5}$ describes the daily changing of those factors for both the existing and the optimization results.
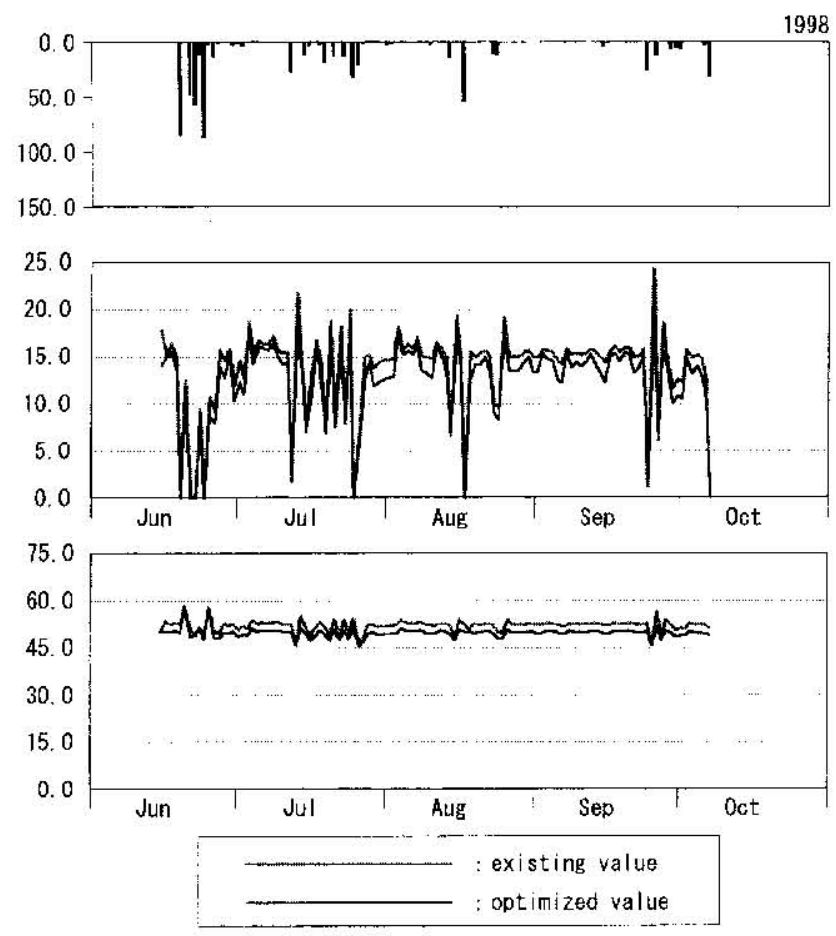

Fig. 5. Change of water supply to paddy fields and the depth of water pond

The figure shows that the difference between the observed and the optimized results is not sigmificantly. Variation and fluctuation patterns between the observed and optimum of water pond and water supply are similar. Both of them are responsive to rainfall. The difference of ponding depth is about $3 \mathrm{~mm}$ where the optimum results are slightly lower than the observed value. This result proves that the actual operation of water supply from creek to paddy fields using pumping in the study area is well enough.

\section{Analysis on the Ratio of Effective Use of Water}

To evaluate more deeply, a quantitative study of the performance of water supply operation is needed. The ratio of effective use of water in paddy fields by pumping $Q_{p p}$ to 
the irrigalion watcr supplicd from the intake gates of the main canal $Q_{\text {mir }}$ for each block of area was clarified as show in Table 2. The efficiency of water use is then called as ratio of water use (Rwu). The amount of water supply from the main canal and water applied to paddy fields by pumping during the irrigation period of 1988 is also given in the table.

The results show that the water supply from the main canal could be optimized. The optimized water supply reduced as compared with the observed one with a range of $16.5 \%-40.3 \%$ from the upper block to the lower block. The water supply from creeks to paddy fields by pumping could be saved around $9.5 \%$. These data can also be used to measure the increasing efficiency in water use by comparing the Ru of the optimum and the observed value. The table shows clearly that application of DDP model will increase the Rwu value. The maximum value of Rwu obtained by the actual water operation at block $\mathrm{E}$ is 3.05 , whereas the optimization gives the maximum value of 3.74 at block $\mathrm{G}$ which is slightly grcater than at block $\mathrm{E}$ of 3.63 . This results malch with the optimum value of water supply from the main canal to creeks in which supply of water for the lowest biock may be saved due to the accumulation of return flow at this block.

Table 2. Observed and optimized ratio of water use

\begin{tabular}{|c|c|c|c|c|c|c|c|c|}
\hline \multirow{2}{*}{ Block } & \multicolumn{2}{|c|}{$\sum Q_{i m \cdot}(\mathrm{IIIII})$} & \multirow{2}{*}{$\begin{array}{c}\Delta Q \\
(\%)\end{array}$} & \multicolumn{2}{|c|}{$\sum Q_{m:}(\mathrm{mm})$} & \multirow{2}{*}{$\begin{array}{l}\Delta Q_{\mu} \\
(\%)\end{array}$} & \multicolumn{2}{|c|}{ Ruiu } \\
\hline & Obs. & Opt. & & Ors. & Opt. & & Obs. & Opt. \\
\hline C & 678.1 & 566.1 & 16.52 & 1569.6 & 1420.8 & 9.48 & 2.315 & 2.510 \\
\hline D) & 801.2 & 556.8 & 30.50 & 1569.6 & 1420.8 & 9.48 & 1.959 & 2.552 \\
\hline E & 515.5 & 391.6 & 24.03 & 1569.6 & 1420.8 & 9.48 & 3.045 & 3.628 \\
\hline F & 830.1 & 600.3 & 27.30 & 1563.6 & 1420.8 & 9.48 & 1.873 & 2.576 \\
\hline G & 637.2 & 380.2 & 40.33 & 1569.6 & 1420.8 & 9.48 & 2.463 & $3.7: 37$ \\
\hline
\end{tabular}

\section{Performance of the Content Ratio of Return Flow}

Quantitative analysis of return flow has been carried out by Jayadi et. al (1998). The amount of relurn flow in creeks was measured in term of the content ratio of total return flow (CTRO) which was defined as a ratio of total amount of surface and secpage runoff return flow to total amount of water storage in creeks. The CTRO value could be used as an indicator for determining water quality condition. The relationship between the change of water quality and CTRO was quite significant in usual fine days for the index of chemical oxygen demand $(C O D)$ and electrical conductivity $(E C)$. A critical value of $C T R O$ was about 0.55 in which if the value is greater than the critical value, there is a high possibility that water quality exceeds the restricted value for paddy rice cultivation.

Based on the above study, the CTRO value resulted from optimization using $D D P$ model need to be considered. By the definition, minimizing water supply from the main canal to creeks $Q_{\text {imc }}$ will increase the CTRO value. The CTRO will be evaluated for fine days simulation only, since the previous study (Jayadi et al, 1998) showed that on the rainy days, if CTRO is greater than 0.7 the water quality index is decreasing. Fig. 6 
compares the CTRO value of existing and simulation based on $Q_{\text {mex }}$ optimum condition. This figure depicts that at the early and the end of July period, the optimized CTRO value is greater than the existing one. This phenomenon also occurred at the mid of August. In the fine days, it shows that there is a tendency of reducing the difference between the existing and the simulated value of CTRO. At block $\mathrm{C}$ and $\mathrm{E}$, the simulation gives the better $C T R O$ value than the existing. However, at block $G$ there is a little increase in CTRO value and the restricted value of water quality seems cannot be satisfied.

As a whole, the simulation results may reduce the performance CTRO as an indicator
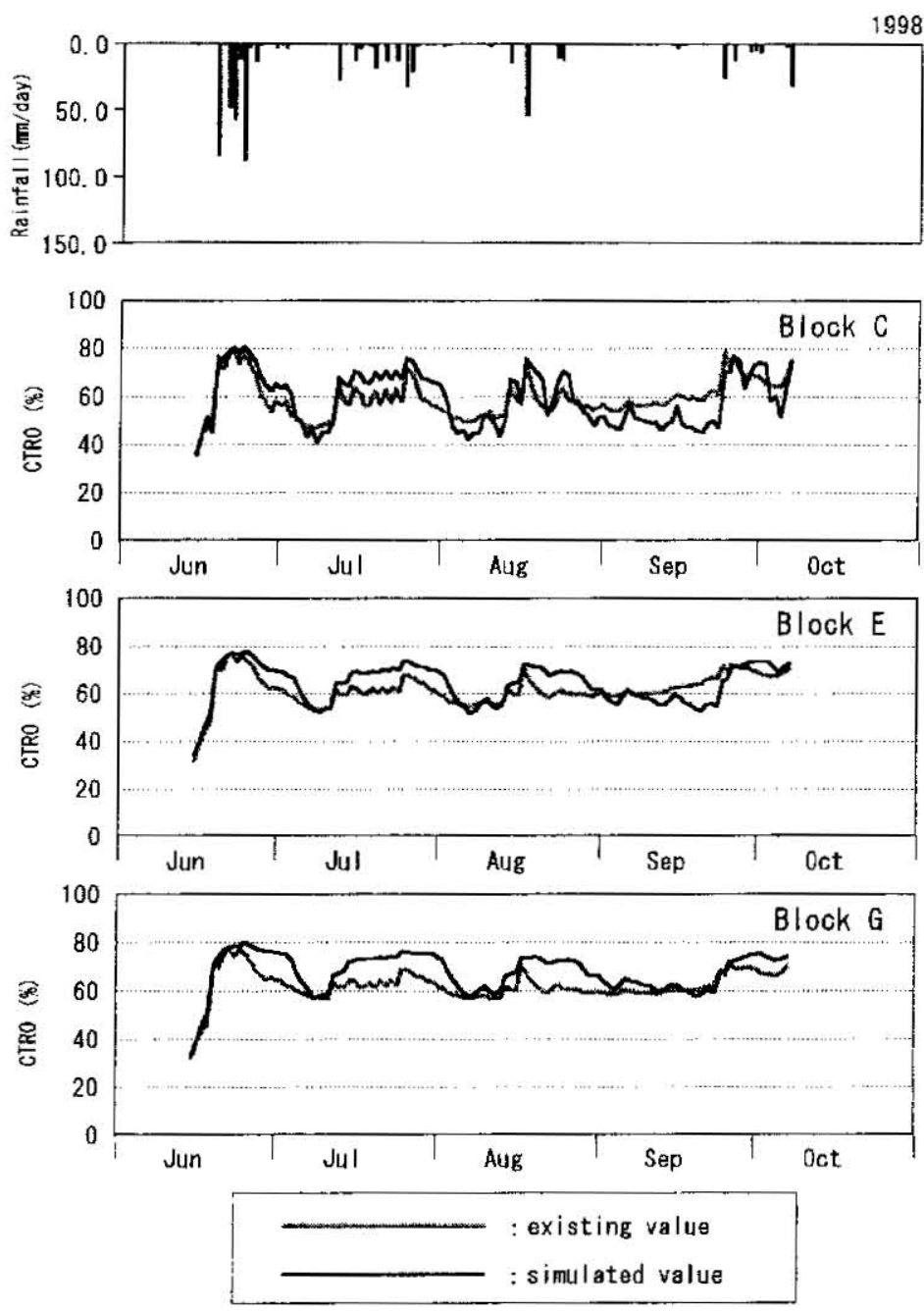

Fig. 6. Fxisting and simulated value of CTRO 
for water quality condition. The increasing CTRO value at the lower block tends to be greater than its upper block. The results show that the irrigation water supply can be optimized, however it will gives a possibility of negative impact to water quality especially at the lower block. For this reason, the model application necds to be improved by considering the water quality constraint

\section{CONCLUSION}

This paper has discussed the application of the deterministic dynamic programming model in optimizing irrigation water supply at low-lying paddy area with creek networks. The characteristics of optimal values of water supply and water use to paddy fields as well as water depth at crecks have been clarified. Waler supply from the main canal to creeks might be optimized, whereas irrigation water supply from creek to paddy fields by pumping is quite efficient.

As a whole the effective use of water can still be optimized. Howcver, the negative impacts to deterioration of water quality must be considered. It can be seen from the increasing of CTRO in the fire days that indicates the decrease in water quality for the indices of $C O D$ and $E C$.

A further study is needed by considering water quality constraints, so that the optimum result can be achieved not only water quantity but also quality.

\section{REFERENCES}

Jayadi, R., T. Fukuda ark M. Kuroda 1998 Reuse Mechanism of Irrigation Return Flow and Its Impact. on Water Quality, froceeding of the $17^{*}$ Congress of APD-LHR, vol. 1, pp. 221230.

Jayadi, R., T. Fukuda, M. Kuroda and Y. Nakaro 1999 Water Reuse and Water Quality in Low-lying Paddy Arca with Creek Networks, Proceeding of the 47" JSIDRE Amnul Congress, pp. 190-191.

Kuroda, Y., and T. Cho 1988 Water Management and Operation of Irrigation System in Low lying Paddy Arca with Creek Network, Joumal of lmigation Engineering and Rural Planming No. 13, The Jupuriese Society of IDRE, pp. 36-46.

Mays, L. W., and Y. K. Tung 1992 Hydrosystems Engineering and Management, WcGrau-Hzll. Inc, New York, pp. 113111. 